\title{
Compost Tea Reduces the Susceptibility of Pinus radiata to Fusarium circinatum in Nursery Production
}

\author{
M. Otero, ${ }^{1, \dagger}$ I. Salcedo, ${ }^{1}$ K. Txarterina, ${ }^{2}$ C. González-Murua, ${ }^{1}$ and M. K. Duñabeitia ${ }^{1}$ \\ ${ }^{1}$ Department of Plant Biology and Ecology, Faculty of Science and Technology, UPV/EHU, Barrio Sarriena s/n, 48940-Leioa, Spain \\ 2 BASALAN S.A., Avenida Madariaga 1, Dpto. 9, 48014 Bilbao, Spain \\ Accepted for publication 22 December 2019.
}

\begin{abstract}
Nutrition is one of the factors that most limits forestry plant growth; thus, current production in nurseries is based on conventional fertilization focused on enhancing vigor. However, an excessive intake of mineral nitrogen can cause morphological imbalances and the formation of more succulent tissues which, consequently, increase susceptibility to plant pathogens. Fusarium circinatum is the causal agent of pitch canker in plants of the Pinus genus, with Pinus radiata being the species most susceptible to this disease. This study compares the response of $P$. radiata seedlings to infection by $F$. circinatum as influenced by two fertilizersconventional and aerated compost tea (ACT) - applied during the nursery phase. The potential of ACT against $F$. circinatum was first tested in vitro, where it was found to inhibit the pathogen's mycelial growth and conidial germination. In the greenhouse, infected plants

fertilized with ACT exhibited less severe internal and external symptoms of pitch canker and lower levels of pathogen colonization of both stems and needles than with conventional fertilizer. An analysis of the hormone content and defense-related gene expression shows greater salicylic acid production and phenylalanine ammonium-lyase and chalcone synthase expression in ACT-fertilized pine. All of the parameters assessed are consistent in showing that biofertilization with ACT reduces the susceptibility of pine seedlings to the disease compared with conventional fertilization.

Keywords: bacteriology, biofertilizer, biological control, defense-related genes, disease control and pest management, hormones, mycology, symptomatology, systemic resistance
\end{abstract}

In 1946, a pathogenic fungus of several pine species was detected in the southeastern United States. In the following decades it spread to populations of Pinus radiata D. Don in California (Britz et al. 2001; Gordon 2006). It was identified as the phytopathogenic ascomycete fungus Fusarium circinatum (Nirenberg and O'Donnell 1998). Since becoming distributed throughout the United States, the pathogen has spread to nurseries and plantations in Australia, Chile, Colombia, Italy, Japan, South Africa, Spain, and New Zealand, probably due to the ability of the fungus to lie dormant in seed or wood of asymptomatic trees (Britz et al. 2001; Schweigkofler et al. 2004; Steenkamp et al. 2012; Wingfield et al. 2008). The disease was named pine pitch canker (Hepting and Roth 1946) and mainly affects conifers of the Pinus genus. However, it has been detected in more than 40 species (Viljoen et al. 1994) in closely related genera. $P$. radiata is the most susceptible Pinus sp. because it has comparatively lower genetic diversity and is cultivated in monocultures over vast areas (Schweigkofler et al. 2004). In Spain, F. circinatum has been detected infecting $P$. pinaster, $P$. radiata, and $P$. sylvestris in both nurseries and forest plantations (Landeras et al. 2005) and has caused widespread alarm due to its potential economic, ecological, and social impact (Wingfield et al. 2001). It is one of the most serious diseases that conifers can suffer anywhere because it progresses rapidly, is efficiently disseminated, and is highly lethal (O'Donnell et al.

\section{${ }^{\dagger}$ Corresponding author: M. Otero; marta.otero@ehu.eus}

Funding: This study was financially supported by the Basque Government (Ekonomiaren Garapen eta Lehiakortasun Saila, Eusko Jaurlaritza, IT-932-16) and the Confederation of Foresters of the Basque Country through a University/ Business contract (US14/04).

*The $e$-Xtra logo stands for "electronic extra" and indicates that supplementary materials are published online.

The author(s) declare no conflict of interest.

(c) 2020 The American Phytopathological Society
1998). Conventional disease control practices are not effective against this species (Reglinski et al. 2004) and F. circinatum is currently on the European and Mediterranean Plant Protection Organization (EPPO) A2 List of pests recommended for regulation as quarantine pests (EPPO code GIBBCI).

$F$. circinatum is capable of causing damage at any time in the pine's life cycle-flowering, seed, seedling, or mature tree (PérezSierra et al. 2007; Wingfield et al. 2008) — and may even be present asymptomatically. In winter, the pycnidia of this fungus are produced on infested needles, branches, and cones. When spring arrives, the conidia infect the tree buds before the needles begin their development and cause the first symptoms of wilting in late spring or early summer. In the nursery, the fungus is typically found on the seed and, when the latter is sown in Sphagnum peat, the pathogen begins to develop, causing the plant to die before or after germinating (Wingfield et al. 2008). Conventionally, this pathogen has been considered airborne, requiring entry through mechanical wounds. However, recently it has been shown that it is able to behave as a soilborne pathogen and infect plants via root penetration, taking advantage of the small wounds produced by formation of new ramifications of secondary roots (MartínRodrigues et al. 2015). Moreover, the structure of the Sphagnum peat acts as a reservoir for $F$. circinatum, due to its porous cavities and the amount of organic matter that it contains (Martín-Rodrigues et al. 2015).

The standard practices for pine production in Basque Country involve conventional fertilizers applied on a slow-release basis to promote vigorous growth, reduce stress, and improve overall tree health (Blodgett et al. 2005). This type of fertilizer alters the original edaphic communities and, due to the large amount of macronutrients applied, can be conducive to the emergence and expansion of pests and increase the susceptibility of plants to phytopathogenic fungal infection (Bengtsson et al. 2005; Konishi et al. 2001). This means that chemical pesticides must be used. The application of such pesticides is increasingly being called into question because of their negative effects on the environment and on human beings. 
Thus, there is growing interest in finding other types of fertilization that maintain the yield and reduce losses due to pests and pathogens.

Compost teas (CTs) are produced by macerating composted remains that contain large populations of microorganisms, many of them beneficial. There are two types of CT, depending on whether the organic matter oxidizes in aerobic conditions or not. Although the most widely studied are nonaerated CTs, aerated compost teas (ACTs) have recently begun to attract more attention. Several of the most abundant microorganisms present in ACTs have been highlighted by different authors as having growth-promoting properties in horticultural plants, among them species of the genera Pseudomonas (Cheng et al. 2007; Patten and Glick 2002; Shaharoona et al. 2008), Serratia (Hameeda et al. 2008; Selvakumar et al. 2008), and Bacillus (Gutiérrez-Mañero et al. 2001; Iqbal et al. 2018; Lateef et al. 2015). Several authors have reported that Bacillus is the most abundant genera followed by Pseudomonas, Serratia, Penicillium, and Trichoderma (Droffner et al. 1995; Kim et al. 2015). The presence of these microorganisms makes CTs a valuable choice because they show an effective ability to suppress phytopathogenic microorganisms (Scheuerell and Mahaffee 2004; Siddiqui et al. 2009; Weltzien 1991), improve soil fertility (Naidu et al. 2010), and stimulate plant enzymes involved in defense against pathogens (Siddiqui et al. 2009). However, to date, there have been no studies of the effect of ACT application on the growth or susceptibility to pathogen infection of trees used in forestry production.

In this study, our aim was to determine whether fertilization with an ACT reduces the susceptibility of $P$. radiata to infection by $F$. circinatum. To that end, the susceptibility to $F$. circinatum of 2-year-old plants produced in a nursery with ACT, as an alternative to conventional fertilization, was tested. In addition, the potential fungicide effect of ACT was also tested in vitro, taking into account the demonstrated infective potential of $F$. circinatum as a soilborne agent in nurseries (Martín-Rodrigues et al. 2015). The value of this work mainly lies in the fact that the effect of ACT on forestry plant health has not previously been described and the results presented here can lay the basis for redirecting current methods of fertilization toward a more sustainable model.

TABLE 1. Physicochemical properties of aerated compost tea

\begin{tabular}{|c|c|}
\hline Parameter & Value $^{z}$ \\
\hline Moisture (wt/wt) & $99.1 \%$ \\
\hline Dry matter (wt/wt) & $0.91 \%$ \\
\hline Density at $20^{\circ} \mathrm{C}(\mathrm{g} / \mathrm{ml})$ & 1.011 \\
\hline $\mathrm{pH}$ & 7.84 \\
\hline Electrical conductivity at $25^{\circ} \mathrm{C}(\mathrm{mS} / \mathrm{cm})$ & 14.3 \\
\hline Oxidation-reduction potential (mV) & -339.25 \\
\hline Ashes (wt/wt) & $0.981 \%$ \\
\hline Total organic matter & $\varnothing$ \\
\hline Total humic extract & $\varnothing$ \\
\hline Nitrogen (total) (wt/wt) & $0.1449 \%$ \\
\hline Nitrogen (ammoniacal) (wt/wt) & $0.0183 \%$ \\
\hline Nitrogen (organic) (wt/wt) & $0.1266 \%$ \\
\hline Total phosphorus $\left(\mathrm{P}_{2} \mathrm{O}_{5}\right)$ & $\varnothing$ \\
\hline Total potassium $\left(\mathrm{K}_{2} \mathrm{O}\right)(\mathrm{wt} / \mathrm{wt})$ & $0.463 \%$ \\
\hline Total calcium $(\mathrm{CaO})(\mathrm{wt} / \mathrm{wt})$ & $0.0131 \%$ \\
\hline Total magnesium (MgO) (wt/wt) & $0.0508 \%$ \\
\hline Total sulfur $\left(\mathrm{SO}_{3}\right)(\mathrm{wt} / \mathrm{wt})$ & $0.0634 \%$ \\
\hline Total sodium $\left(\mathrm{Na}_{2} \mathrm{O}\right)(\mathrm{wt} / \mathrm{wt})$ & $2.037 \%$ \\
\hline Total boron (B) (mg/kg) & 2.56 \\
\hline Total iron $(\mathrm{Fe})$ & $\varnothing$ \\
\hline Total manganese (Mn) & $\varnothing$ \\
\hline Total zinc (Zn) (mg/kg) & 0.92 \\
\hline Vitamin B1(mg/kg) & 1.21 \\
\hline Vitamin B2, B3, C, E, and B9 & $\varnothing$ \\
\hline Gibberellins (GA), cytokinins (CK), and auxins & $\varnothing$ \\
\hline
\end{tabular}

z Symbol $\varnothing$ indicates value below the detection threshold.

\section{MATERIALS AND METHODS}

Physicochemical and microbiological characteristics of ACT. The compost used was produced by GARBIKER AB, S.A. and consisted of $90 \%$ agricultural waste (mainly cabbage, kale, red cabbage, pumpkin, and tomato) from large producers and $10 \%$ garden waste. The production of ACT is detailed in the Materials and Methods section of Otero et al. (2019) but is briefly described here. To produce the aerated tea, this compost was mixed with water (1:10 compost/water [wt/vol]) in a brewing tank and fermented at room temperature $\left(22 \pm 2^{\circ} \mathrm{C}\right)$ for at least 4 days with continuous aeration supplied by an aquarium pump (Naidu et al. 2010). In addition, based on the results obtained by Naidu et al. (2010), yeast extract ( $7 \mathrm{~g}$ per $100 \mathrm{~g}$ of compost) was added to increase the microbial populations in the ACT. Once fermentation was completed, the solid fraction was removed, and the extract was stored in polyethylene barrels in darkness at room temperature until use.

The physicochemical properties of the fermented extract were determined by Fitosoil Laboratorios S.L. using inductively coupled plasma atomic emission spectroscopy and ionic chromatography in accordance with the relevant UNE-EN ISO standards and Regulation (CE) number 2003/2003 of the European Parliament and are detailed in Table 1. The microbial DNA was extracted by a modified version of the cetyltrimethylammonium bromide (CTAB) procedure described by Möller et al. (1992), detailed in the "Quantification of plant hormones, defense-related gene expression and pathogen present in pine tissues" section. Metabarcoding analysis was performed by the Genomics and Proteomics Service of SGIKER (UPV/EHU) following the protocol "16S metagenomic Sequencing Library Preparations" by Illumina, available on its website (https://support.illumina.com/documents/documentation/ chemistry_documentation/16s/16s-metagenomic-library-prepguide-15044223-b.pdf), using an MiSeq sequencer. The sequences from the metagenomic analysis were contrasted in the Silva database (https://www.arb-silva.de/). The sequences were analyzed within Quantitative Insights Into Microbial Ecology (QIIME 1.9) (Caporaso et al. 2010). The taxonomy was assigned to each representative sequence of bacteria and archaea using SILVA 119. Sequences were clustered into operational taxonomic units with UCLUST (Edgar 2010), using reference approaches with a $97 \%$ identity threshold. The cultivable microorganisms in the CT were analyzed by using Sanger sequencing following the protocol of Murray and Thompson (1980). The sequences generated after Sanger sequencing were compared with the sequences available in the NCBI.

Plant and fungal growth. The Fc-GFP1 strain, an $F$. circinatum isolate transformed with a green fluorescent protein (GFP) (Martín-Rodrigues et al. 2013), was used to assess the effect of ACT on pathogen development and the susceptibility of $P$. radiata. Fungal cultures were established from colonies resulting from the subculture of a single conidium (stored in $25 \%$ glycerol [vol $/ \mathrm{vol}]$ at $-80^{\circ} \mathrm{C}$ ) and were routinely grown at 22 to $28^{\circ} \mathrm{C}$ on potato dextrose agar (PDA) for up to 2 weeks. $P$. radiata seed were obtained from an orchard belonging to the Basque Country's Genetic Improvement Program.

In vitro experiment. The direct fungistatic effects of ACT on pathogen growth, mycelial biomass, mycelial radial growth, and conidia germination were assessed using in vitro studies on amended media. The preparation of the culture media was carried out as follows. To obtain 0, 25, 50, 75, and 100\% (vol/vol) ACT concentrations in each flask, the same amount of PDA agar (39 $\mathrm{g}$ liter $^{-1}$ ) was added to each one and then 1,000, 750, 500, $250 \mathrm{ml}$, and $0 \mathrm{ml}$ of distilled water, respectively, was poured into the flask. Because ACT contains live microorganisms and thermosensitive molecules, it was decided to add only $100 \mathrm{ml}$ of ACT to the flask which was assigned the $100 \%$ concentration to dissolve the agar and then pour the rest when the mix had been tempered and not 
completely solidified. The same procedure was followed for the rest of the flasks, carefully adding the remaining $0,250,500,750$, and $900 \mathrm{ml}$ of ACT while gently shaking the flask containing the sterilized, molten PDA medium prior to pouring $10 \mathrm{ml}$ into $90-\mathrm{mm}-$ diameter Petri dishes. After that, a mycelial disk ( $5 \mathrm{~mm}$ in diameter) obtained from the edge of a 14-day-old $F$. circinatum colony was placed at the center of the PDA agar plate and sealed with parafilm. Plates were incubated for 14 days in darkness at $25^{\circ} \mathrm{C}$. Then, colony growth was measured as the area of media covered by mycelium and mycelium biomass according to the protocol described by Eng et al. (2003).

To assess the effect of ACT on germination, conidia were extracted from 14-day-old colonies grown on PDA by adding $10 \mathrm{ml}$ of sterile $\mathrm{KCl}$ at $0.5 \%$ (wt/vol) and scraping with a scalpel from the surface of the colony. The concentration of the suspension was adjusted to $10^{3}$ conidia $\mathrm{ml}^{-1}$ using a hemocytometer. Petri dishes containing the amended medium were inoculated by spreading a $0.1 \mathrm{ml}$ aliquot of the suspension on each amended plate. Plates were incubated for 7 days in darkness at $25^{\circ} \mathrm{C}$. After the incubation period, the germinated colonies were visually counted and, knowing the inoculated initial concentration, the percentage of inhibition was calculated.

Greenhouse experiment. The standard production process of $P$. radiata begins with staggered sowing in containers, which are maintained outdoors for a minimum of 9 months and later removed. For this work, the experiment was conducted in the forest nursery of BASALAN S.A. in Bizkaia, Spain. Two batches of pine seed were sown in December and March over a mixture of white and black Sphagnum peat $(70: 30$ [vol/vol]) in Arnabat trays of 35 cells $\left(200 \mathrm{~cm}^{3}\right)$. Each tray was an experimental unit, and trays were arranged in a randomized block design, dividing the experiment into three blocks. During their time in the nursery, seedlings were maintained under regular irrigation and received three different types of fertilization: (i) control, in which plants received only water during their growth; (ii) conventional, in which the slow-release fertilizer Plantacote Plus 14:18:15 NPK + $2 \mathrm{Mg}$ (Aglukon, Düsseldorf, Germany) was mixed with peat substrate at the recommended dose of $3 \mathrm{~g} /$ liter prior to filling the trays (Ortega et al. 2006); and (iii) ACT, in which the CT was applied once a month by directly watering the substrate with $50 \mathrm{ml}$ of an aqueous dilution of 1:5 ( vol/vol). At the end of this period in the nursery, the conventional fertilized plants had received $0.84,1.08$, and $0.9 \mathrm{~g}$ of nitrogen, phosphorus, and potassium respectively, by fertilization. The plants fertilized with ACT received a total of $0.1,0.0$, and $0.41 \mathrm{~g}$ of nitrogen, phosphorus, and potassium respectively, by fertilization.

After 9 months, arbitrarily selected plants were transplanted into QuickPot trays of 6 cells $\left(1,600 \mathrm{~cm}^{3}\right)$, using the same substrate mixture. For each batch, 54 trays were prepared, 18 for each of the three fertilization treatments (water, conventional, and ACT). These plants continued growing in the nursery up to the age of 17 months. Then, they were moved into a high-security glasshouse under controlled conditions ( $85 \%$ relative humidity, with a 12 -h photoperiod, providing $300 \mu \mathrm{mol} \mathrm{m} \mathrm{m}^{-2} \mathrm{~s}^{-1}$ photosynthetic active radiation) and, after a 4-week acclimatization period, the inoculation was carried out.

The 54 trays of plants were divided into three different homogeneous sets for different purposes. Set 1 was inoculated with $F$. circinatum and used for most of the data in the study. In total, 27 plants were destructively sampled 2 days after inoculation, 18 of which were used for hormone quantification and 9 of which used for quantifying gene expression. The remaining plants were rated for whole-plant disease symptoms once weekly for 14 weeks. During this period, 36 of the remaining plants showing wilting symptoms were processed to determine canker length under the bark and necrotic area of cross sections, and 12 of the remaining plants were processed to quantify the amount of pathogen present in host tissue. Set 2 received a $1-\mu$ l droplet of distilled sterile water (mock inoculation) and, from here, 18 plants were processed for noninfected plant hormone quantification. Set 3 was left unmanipulated as a negative environmental control. Thirty plants from this last set were biometrically characterized by measuring their height, root collar diameter, and shoot or root dry biomass after drying at $80^{\circ} \mathrm{C}$ for $48 \mathrm{~h}$. The inoculation process consisted of removing one needle fascicle from the middle of the stem and adding a $1-\mu l$ droplet of the conidia suspension $\left(2.5 \times 10^{5}\right.$ conidia $\mathrm{ml}^{-1}$ ) or sterile water directly at the wound site (Martín-Rodrigues et al. 2013).

Two ratings of disease severity, one based on aerial symptoms of the plant and the other on the amount of resin exuded, were obtained weekly through 14 weeks postinoculation. The rating scale for aerial disease symptoms was as follows: $1=$ healthy plant with no necrosis, 2 = healthy plant with necrosis only at the inoculation point, $3=$ necrosis $2 \mathrm{~cm}$ above and below the point of inoculation, $4=$ wilting with crown dieback, and $5=$ reddening foliage above the point of inoculation (Correll et al. 1991). The rating scale for the amount of resin exuded was as follows: $0=$ low resin exudation, $1=$ moderate exudation, $2=\leq 0.5 \mathrm{~cm}$ from the wound, $3=>0.5$ and $<4 \mathrm{~cm}$ from the wound, and $4=>4 \mathrm{~cm}$ from the wound (Bonello and Blodgett 2003). With these data, the disease progression rate (DPR) was calculated using the formula DPR $=\Sigma i X_{i} / n$, where $X_{i}=$ average of severity degrees and $n=$ weeks after inoculation.

In order to verify the real extent of the symptomatology, the bark was removed from the stems of some of those plants. In all, 18 plants showing irreversible signs of wilting (severity scale of 5) and 18 plants apparently asymptomatic (severity scale of 1 ) were chosen at the end of the experiment. The procedure consisted of making longitudinal sections so as to measure with a ruler the canker length and transversal sections to determine the necrotic area using ImageJ software.

Quantification of plant hormones. Hormone content was analyzed at 2 days postinfection by sending a pool of pulverized and lyophilized stems and needles from infected and uninfected pine trees to the CETEMAS Research Institute (Technological and Forestry Center for Wood) in Asturias, Spain. Hormone detection and quantification was carried out by liquid chromatography (LC) (ultrahigh-performance LC, Agilent 1290 Infinity; Agilent) with a triple quadrupole mass detector (Agilent 6460 Triple series Quad LC mass spectrometry; Agilent).

The plant material used in the experiments that followed consisted of $2-\mathrm{cm}$ sections of the stems $(1 \mathrm{~cm}$ above and below the inoculation point) and the needles around them, which were then pulverized using liquid nitrogen and a mortar and stored at $-80^{\circ} \mathrm{C}$ until use.

Defense-related gene expression. To assess the influence of fertilizer treatment on the plant's defense response, we quantified the expression of genes within the pathogenesis-related (PR) protein family (chitinase [QUI] and glucanase [GLU]) or those that are involved in the synthesis of secondary metabolites of proven antimicrobial action (phenylalanine ammonium-lyase [PAL], chalcone synthase [CHS], and hydroxymethylglutaryl-CoA reductase 2 [HMG-CoA2]) in needles and stems of plants 2 days after inoculation. To determine gene expression, a modified version of the method described by Chang et al. (1993) was used to extract RNA. This modification consisted of adding two volumes of cold isopropanol to the sample with $\mathrm{LiCl}$, letting the RNA precipitate at $-20^{\circ} \mathrm{C}$ for $2 \mathrm{~h}$ before centrifuging, and, finally, adding $100 \%$ ethanol to wash the sample. To remove the DNA, the Recombinant DNase I (RNase-free) kit from Takara (Clontech Laboratories Inc.) was used following the manufacturer's instructions. For enzyme elimination, phenol-chloroform extraction was chosen. Finally, the pellet was resuspended in $50 \mu \mathrm{l}$ of sterile ultrapure water and kept at $-20^{\circ} \mathrm{C}$ until use. Subsequently, sample concentration was standardized and the retrotranscription reaction was carried out using the PrimeScript RT reagent kit (Perfect Real Time) from Takara (Clontech Laboratories Inc.). The reaction and the PCR program were prepared according to the manufacturer's instructions. 
Once the complementary DNA was obtained, the quantitative PCR was prepared with the following final concentrations: $1 \times$ SYBR, $0.2 \mu \mathrm{M}$ each primer, $1 \times \mathrm{ROX}$, and $2 \mu \mathrm{l}$ of cDNA in a final volume of $15 \mu \mathrm{l}$. The sequences of the primers used are described in Table 2. These genes were selected because they are within the PR protein family (QUI and GLU) or because they are involved in the synthesis of secondary metabolites of proven antimicrobial action.

The PCR program was implemented in a StepOne Plus thermocycler (Applied Biosystems) and consisted of an initial denaturation at $94^{\circ} \mathrm{C}$ for $10 \mathrm{~min}$; followed by 45 cycles of denaturation at $94^{\circ} \mathrm{C}$ for $15 \mathrm{~s}$ and annealing or elongation at $60^{\circ} \mathrm{C}$ for $1 \mathrm{~min}$; and ending with an automatic final cycle which consisted of continuously measuring the fluorescence emitted in the range of 60 to $95^{\circ} \mathrm{C}$, increasing the temperature $0.2^{\circ} \mathrm{C} / \mathrm{s}$. This step enables the dissociation kinetics of the amplified fragments to be monitored and the melt curve to be determined. The calculation of the expression was carried out by relative quantification applying the formula $2^{--\Delta \mathrm{CT}}$, with $\Delta \mathrm{C}$ T being the difference between the cycle threshold (СТ) of the incognita gene and the CT of the housekeeping gene. The housekeeping gene used in this experiment was $N L Y$ (Martín-Rodrigues et al. 2013).

Quantification of the pathogen present in pine tissues. After disease severity was assessed in the greenhouse experiment, the fungus present in the plant tissues was quantified. DNA was extracted using a modified version of the CTAB procedure described by Möller et al. (1992). This modification consisted of adding $1,250 \mu \mathrm{l}$ of cold isopropanol after adding $\mathrm{LiCl}$ and allowing DNA to precipitate for $24 \mathrm{~h}$ at $-20^{\circ} \mathrm{C}$ before centrifuging. The SYBR Premix Ex TaqTM (TliRNaseH Plus) kit from Takara (Clontech Laboratories Inc.) was used to prepare the reaction. The primers used and the PCR procedure followed were as described by Martín-Rodrigues et al. (2013), with the following final concentrations: $1 \times$ SYBR, $0.2 \mu \mathrm{M}$ each primer, $1 \times \mathrm{ROX}$, and DNA at $1 \mathrm{ng} / \mu \mathrm{l}$ in a final reaction volume of $15 \mu \mathrm{l}$. The calculation of the expression was made by absolute quantification, having previously made a regression line with different concentrations of DNA and their different $\mathrm{C}_{\mathrm{T}}$ values. Once the DNA concentration of the sample was obtained, in order to normalize the samples, the nanograms per microliter of the FCIR gene were divided between the $N L Y$ gene (housekeeping) concentration values (Martín-Rodrigues et al. 2013).

Statistical analyses. The data obtained from the two rounds carried out over time were merged for the statistical analyses, which were carried out using SPSS Statistics software (v.18; IBM). In order to identify differences between treatments in the case of the in vitro experiment, defense gene induction, and pathogen concentration assays, one-way analysis of variance (ANOVA) and the $t$ test were used. As post hoc tests, S-N-K and Tukey were used if the homogeneity of variances was met, and Dunnett's $C$ if it was not. Due to the lack of independence of the data, in the disease progression experiment, the data were treated using a repeatedmeasures ANOVA. In addition, to check the dissimilarity between the different blocks and treatment groups in canker dimensions, pine plant growth, and defense hormone concentration experiments, a linear mixed model was used, stipulating that the fixed effects were the different nutritional treatments and the random effects were the blocks. In all cases, it was determined that there was statistical significance for values of $\alpha \leq 0.05$.

\section{RESULTS}

Physicochemical and microbiological characteristics of ACT. The results for both the analysis of bacterial metagenome and the count of cultivable species are shown in Table 3. The predominant phyla detected in the CT were, in descending order, Bacteroidetes, Firmicutes, and Proteobacteria. The main cultivable species were Ochrobactrum tritici, Pseudomonas aeruginosa, Gordonia terrae, Bacillus subtilis, and B. licheniformis.

In vitro experiment. In all of the parameters studied in vitro to test the ACT effect on Fusarium development, an inhibitory trend was noted even at low ACT concentrations (25\%). However, significant differences were observed in the development of the

TABLE 3. Most abundant bacterial phyla detected by metagenomic analysis and representativeness of the main microbial species detected after the count of colony forming units in Petri dishes

\begin{tabular}{|c|c|}
\hline Phylum or species & Percentage $(\%)$ \\
\hline \multicolumn{2}{|l|}{ Metabarcoding } \\
\hline Bacteroidetes & 15.6 \\
\hline Firmicutes & 15.5 \\
\hline Proteobacteria ( $\beta$-proteobacteria) & 14.5 \\
\hline Proteobacteria ( $\alpha$-proteobacteria) & 13.7 \\
\hline Proteobacteria $(\delta$-proteobacteria) & 11.6 \\
\hline Others & 6.1 \\
\hline Spirochaetes & 4.6 \\
\hline Synergistetes & 4.5 \\
\hline Proteobacteria ( $\gamma$-proteobacteria) & 4.4 \\
\hline Tenericutes & 3.6 \\
\hline Proteobacteria ( $\varepsilon$-proteobacteria) & 2.8 \\
\hline Actinobacteria & 1.7 \\
\hline Euryarchaeota & 1.4 \\
\hline \multicolumn{2}{|l|}{ Cultivable microorganisms } \\
\hline Ochrobactrum tritici & 24.53 \\
\hline Pseudomonas aeruginosa & 17.41 \\
\hline Gordonia terrae & 15.83 \\
\hline Bacillus subtilis & 14.24 \\
\hline B. licheniformis & 11.87 \\
\hline B. pumilus & 5.54 \\
\hline B. safensis & 4.75 \\
\hline B. velezensis & 3.96 \\
\hline Serratia marcescens & 1.58 \\
\hline P. fluorescens & 0.14 \\
\hline P. putida & 0.12 \\
\hline Fungal species & 0.04 \\
\hline
\end{tabular}

TABLE 2. Sequences of the primers used to detect the induction of plant defense-related genes

\begin{tabular}{|c|c|c|c|c|}
\hline Gene name & GenBank access & Primer name ${ }^{z}$ & Primer sequence $\left(5^{\prime}-3^{\prime}\right)$ & Citation \\
\hline \multirow[t]{2}{*}{ Chitinase class III } & 4327172 & QUI-F & AAATCTTCAGCATCGCCA & Boava et al. 2010 \\
\hline & $\ldots$ & QUI-R & CCCAATAGACAGCAATTTCTC & $\cdots$ \\
\hline \multirow[t]{2}{*}{ Glucanase } & 103498635 & GLU-1 & TTYGATGCYMTKKTGGAT & Rivera et al. 2002 \\
\hline & $\ldots$ & GLU-2 & TCRTCARACATRGCRAA & $\ldots$ \\
\hline \multirow[t]{2}{*}{ Phenylalanine ammonium-lyase } & JQ765748.1 & PAL-F & AGAACACGGTGAGCC & Jin et al. 2013 \\
\hline & $\ldots$ & PAL-R & CATAGGCAAGCACATA & $\cdots$ \\
\hline \multirow[t]{2}{*}{ Chalcone synthase } & AJ413277 & CHS-F & GGGAATCAACGGTTTTGGAA & De Keyser et al. 2013 \\
\hline & $\ldots$ & CHS-R & CTCGGGCTTAAGGCTCAACTT & 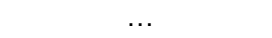 \\
\hline \multirow[t]{2}{*}{ Hydroxymethylglutaryl-CoA reductase 2} & AF110383 & HMG2-F & ATTACCTTCAGAATGAATACGCT & Villar-Luna et al. 2015 \\
\hline & $\ldots$ & HMG2-R & СTCTCTATGTTTTGTGCTGGGT & $\ldots$ \\
\hline
\end{tabular}

z Chitinase (QUI), glucanase (GLU), phenylalanine ammonium-lyase (PAL), chalcone synthase (CHS), and hydroxymethylglutaryl-CoA reductase 2 (HMG2). 
pathogen at different concentrations: the greatest biomass inhibition occurred at concentrations of 75 and $100 \%$, where growth in biomass was reduced by 30 and $38 \%$, respectively; the highest area reduction was observed at a concentration of $75 \%$, where growth in area was reduced by $45 \%$; and the greatest germination inhibition occurred at a concentration of $100 \%$, showing a reduction in conidia germination of $79 \%$ (Fig. 1). All of these percentages have been normalized with respect to the control values $(0 \%)$.

Plant growth. Biometric values for plants fertilized with the conventional treatment were 8,31 , and $50 \%$ higher for height and grams of dry weight of needles and stem, respectively, when compared with ACT-fertilized plants. The roots of the ACT-fertilized pine showed the highest biomass but it was not significantly different from conventionally fertilized roots (Table 4).

Greenhouse experiment. For disease symptoms, the DPR showed significant differences between plants fertilized with ACT and the rest of the treatments; in this case a lower index was observed in ACT-fertilized plants at 98 days (14 weeks) postinoculation. Disease severity DPR values on the final rating date were 33 and $22 \%$ higher in water and conventional treatments, respectively, when compared with ACT-treated plants. This pattern contrasted with that of resin, in which the degree of resination in water presented significant differences compared with the conventional treatment. However, statistical analysis did not detect differences between conventional and ACT treatments (Fig. 2).

Canker length was significatively smaller (67\%) in the pine trees fertilized with ACT than in those fertilized conventionally (Fig. 3). The same trend was observed in the percentage of necrotic area, which was $26 \%$ lower. As for the presumed asymptomatic pine trees, it was found that, although they did not show external signs of disease, on the inside they displayed tissue necrosis. Those asymptomatic pine trees fertilized with ACT also had the lowest percentage of affected tissue (Fig. 3).

Quantification of plant hormones. In relation to hormone content, infected pine trees with conventional fertilizer showed significant increases of 19,31 , and $62 \%$ in indolacetic acid,

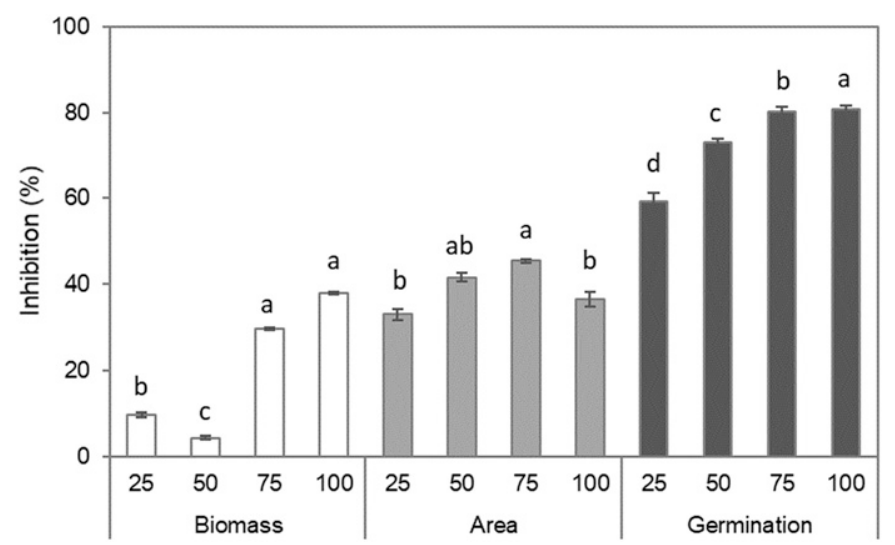

Fig. 1. Effect of increases in the concentration of aerated compost tea $(25,50$, 75 , and $100 \%$ ) on colony area, biomass, and conidia germination rate inhibition of Fusarium circinatum compared with control treatment $(0 \%)$. Sample size $=10$. Means with different letters within each variable are statistically different $(\alpha \leq 0.05)$ based on the $P$ values obtained using the analysis of variance test. Error bars indicate the standard error. gibberellins, and brassinosteroids, respectively, compared with those irrigated with water. The ACT-fertilized infected pine showed a significant increase in concentration of $208 \%$ in salicylic acid and $33 \%$ in brassinosteroids compared with conventional-fertilized infected plants. In the case of brassinosteroids, the increase was especially notable for castasterone and brassinolides. In the latter treatment, the concentration of salicylic acid increased to the detriment of all other stress hormones but especially gibberellins (Table 5).

Defense-related gene expression. The change in relative expression in response to $F$. circinatum inoculation was significantly higher in ACT-fertilized plants compared with conventional or water for QUI in stems, PAL in both needles and stems, and HMG-CoA2 in stems (Fig. 4). No differences were found in the expression of the HMG-CoA2 gene in the needles of any of the treatments.

Quantification of the pathogen present in pine tissues. The amount of fungus found in the stem of symptomatic plants was significantly higher $(17.73 \%)$ in conventionally fertilized pine trees than in those grown with ACT. The same trend was observed in the case of asymptomatic pine, where the amount of the pathogen was significantly higher $(99.94 \%)$ in stems of conventionally fertilized pine. This trend was also observed in the amount of fungus present
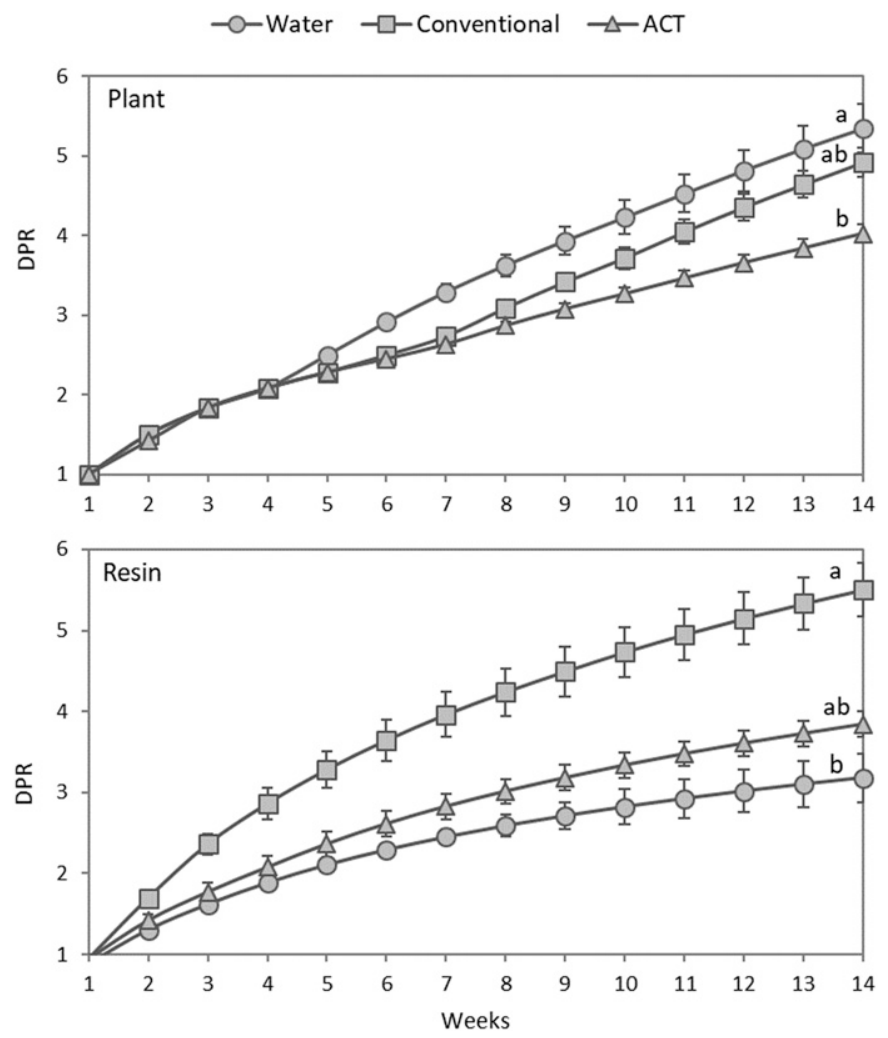

Fig. 2. Disease progression rate (DPR) based on degree of plant severity and degree of resin exudation observed at 98 days after inoculation with Fusarium circinatum of Pinus radiata plants grown for 18 months in a nursery with water, conventional fertilizer, and aerated compost tea (ACT). Sample size = 18. Means with different letters within each variable are statistically different $(\alpha \leq 0.05)$ based on the $P$ values obtained using the repeated measures analysis of variance test. Error bars indicate the standard error.

TABLE 4. Growth of 18-month-old noninoculated pine trees as influenced by fertilizer treatment ${ }^{\mathrm{z}}$

\begin{tabular}{lccccc}
\hline Treatment & Height $(\mathrm{cm})$ & Diameter $(\mathrm{mm})$ & Needles $(\mathrm{gDW})$ & Stem $(\mathrm{gDW})$ & Root $(\mathrm{gDW})$ \\
\hline Water & $22.9 \pm 1.1 \mathrm{~b}$ & $3.5 \pm 0.21 \mathrm{~b}$ & $1.1 \pm 0.17 \mathrm{c}$ & $0.5 \pm 0.05 \mathrm{c}$ & $1.3 \pm 0.14 \mathrm{~b}$ \\
Conventional & $66.6 \pm 2.1 \mathrm{a}$ & $7.7 \pm 0.46 \mathrm{a}$ & $7.4 \pm 0.58 \mathrm{a}$ & $6.8 \pm 0.95 \mathrm{a}$ & $9.4 \pm 0.36 \mathrm{ab}$ \\
Aerated compost tea & $61.4 \pm 1.3 \mathrm{ab}$ & $7.2 \pm 0.19 \mathrm{a}$ & $5.1 \pm 0.78 \mathrm{~b}$ & $3.4 \pm 0.26 \mathrm{~b}$ & $10.7 \pm 0.39 \mathrm{a}$ \\
\hline
\end{tabular}

${ }^{\mathrm{z}}$ Means within a measurement column followed by different letters are statistically different $(\alpha \leq 0.05)$ based on the $P$ values obtained using the linear mixed model. $\mathrm{gDW}=$ grams dry weight and symbol \pm indicates mean standard error above and below average. 
in needles: under conventional fertilization, it was $96.59 \%$ higher than in ACT in the needles of symptomatic plants and $99.88 \%$ higher for asymptomatic plants (Fig. 5).

\section{DISCUSSION}

This research found that ACT reduced the severity of pitch canker of Pinus radiata caused by $F$. circinatum. This was due to limitation in the development and progression of the pathogen compared with conventional fertilization.

The ACT assessed here is a liquid organic matrix which contains a low concentration of macro- and micronutrients and vitamins, but whose main importance lies in its concentration of microorganisms from different genera, which coexist and act synergistically, increasing the benefits for the plants to which it is applied. The most abundant microorganisms in the ACT used in this research were species of, in descending order, Bacillus (40.4\%), Ochrobactrum (24.5\%), Pseudomonas (17.7\%), Gordonia (15.8\%), and Serratia (1.6\%). Similarly, Kim et al. (2015) found that Bacillus (63\%) and Ochrobactrum (13\%) were the two most abundant bacteria in a tea obtained from composting of rice straw, vermicompost, and cypress bark.

ACTs are considered effective biofertilizers because they contain a rich microbial community composed of nitrogen-fixing bacteria and phosphorus and potassium solubilizers, many of which are described as plant-growth-promoting rhizobacteria. Fungi account for only $1 \%$ but include species of the genera Aspergillus and Penicillium that add value to the product by being plant-growthpromoting fungi.

The ACT used in this study was found to be directly antagonistic to $F$. circinatum in vitro. In these fertilizers, predominate bacterial species of the genera Bacillus and Pseudomonas, Actinomyces and acid-lactic bacteria, and fungi in Trichoderma and other genera (Naidu et al. 2010; Siddiqui et al. 2009; Welke 2005) are found. These have been shown over the years to have an antagonistic effect on pathogens (Allona et al. 1996; Cheah and Page 1997; Domracheva et al. 2010; Veluthakkal and Dasgupta 2010). That effect was found in our work via the assay in which $F$. circinatum was cultured in plates with increasing concentrations of ACT. It was observed that, with a concentration of just $25 \%$, there was significant inhibition of growth and viability of conidia compared with the control $(0 \%)$, which helped to reduce their presence in the substrate (in this case peat) where ACT was applied. The use of these CTs as fertilizers would thus also be desirable in the case of infections of $P$. radiata roots that are initiated by inoculum in peat, because this fungus is able to survive in Sphagnum peat and infect $P$. radiata roots, as Martín-Rodrigues et al. (2015) demonstrate in their article.

It has also been proven that the microorganisms present in CTs are capable of both stimulating the induced resistance of plants and inhibiting pathogenic microorganisms by antibiosis mechanisms, parasitism, and competition for resources (Kai et al. 1990; Kim et al. 2015; Palmer et al. 2010; Scheuerell and Mahaffee 2002; Siddiqui et al. 2009; Weltzien 1991). In their review, Scheuerell and Mahaffee (2002) emphasized the importance of preinfection application and frequency of fertilization as a preventive treatment, which would depend mainly on the pathogen reproductive rates, propagation methods, and environmental conditions. Due to this phenomenon of displacement by competition, CT can be applied as an undiluted foliar spray to attempt to cover at least 60 to $70 \%$ of the surface area. The natural niche of most of the bacteria and fungi
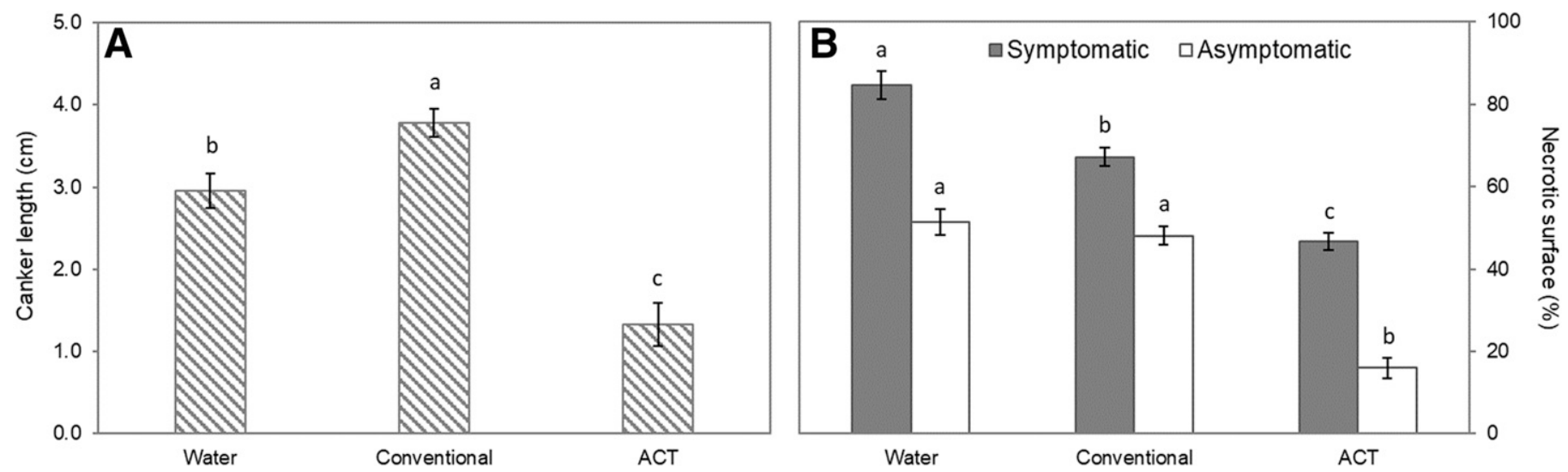

Fig. 3. A, Canker length (in centimeters) and $\mathbf{B}$, percentage of necrotic surface in a cross section of the stem of symptomatic and asymptomatic Pinus radiata plants, grown for 18 months with water, conventional fertilizer, and aerated compost tea (ACT). Sample size $=12$. Means with different letters within each variable are statistically different $(\alpha \leq 0.05)$ based on the $P$ values obtained using the linear mixed model. Error bars indicate the standard error.

TABLE 5. Concentration of stress, growth, and defense hormones in 18-month-old pine trees without infection (-Fc) and 2 days after inoculation with Fusarium circinatum $(+\mathrm{Fc})$ for different types of fertilization ${ }^{\mathrm{x}}$

\begin{tabular}{|c|c|c|c|c|c|c|c|c|c|}
\hline \multirow[b]{2}{*}{ Fertil. $^{y}$} & \multicolumn{9}{|c|}{ Hormones $(\mu \mathrm{g} / \mathrm{g}$ of tissue $)$} \\
\hline & Abscisic acid & Jasmonic acid & Salicylic acid & Indolacetic acid & Cytokinins & Gibberellins & Brassinosteroids & Castasterone $^{z}$ & Brassinolides $\mathrm{z}$ \\
\hline \multicolumn{10}{|l|}{$-\mathrm{Fc}$} \\
\hline Water & $0.11 \pm 0.00 \mathrm{NS}$ & $0.00 \pm 0.00 \mathrm{NS}$ & $0.04 \pm 0.01 \mathrm{NS}$ & $0.11 \pm 0.01 \mathrm{~b}$ & $0.31 \pm 0.01 b$ & $0.05 \pm 0.00 \mathrm{~b}$ & $10.74 \pm 0.46 \mathrm{NS}$ & $8.64 \pm 1.37 \mathrm{NS}$ & $1.38 \pm 0.19 \mathrm{a}$ \\
\hline Conv & $0.14 \pm 0.01 \mathrm{NS}$ & $0.00 \pm 0.00 \mathrm{NS}$ & $0.03 \pm 0.01 \mathrm{NS}$ & $0.31 \pm 0.02 \mathrm{a}$ & $0.30 \pm 0.01 \mathrm{~b}$ & $0.08 \pm 0.01 \mathrm{a}$ & $9.47 \pm 0.76 \mathrm{NS}$ & $6.98 \pm 1.16 \mathrm{NS}$ & $0.87 \pm 0.12 b$ \\
\hline ACT & $0.16 \pm 0.01 \mathrm{NS}$ & $0.00 \pm 0.00 \mathrm{NS}$ & $0.04 \pm 0.03 \mathrm{NS}$ & $0.19 \pm 0.01 \mathrm{~b}$ & $0.43 \pm 0.02 \mathrm{a}$ & $0.08 \pm 0.01 \mathrm{a}$ & $9.39 \pm 0.96 \mathrm{NS}$ & $6.68 \pm 1.13 \mathrm{NS}$ & $1.35 \pm 0.18 \mathrm{a}$ \\
\hline \multicolumn{10}{|l|}{$+\mathrm{Fc}$} \\
\hline Water & $0.15 \pm 0.01 \mathrm{NS}$ & $0.09 \pm 0.02 \mathrm{a}$ & $0.10 \pm 0.01 b$ & $0.14 \pm 0.01 b$ & $0.11 \pm 0.02 \mathrm{NS}$ & $0.06 \pm 0.03 b$ & $5.73 \pm 0.72 \mathrm{c}$ & $4.57 \pm 0.48 b$ & $1.11 \pm 0.09 \mathrm{~b}$ \\
\hline Conv & $0.15 \pm 0.01 \mathrm{NS}$ & $0.00 \pm 0.00 \mathrm{~b}$ & $0.06 \pm 0.00 \mathrm{c}$ & $0.16 \pm 0.01 \mathrm{a}$ & $0.11 \pm 0.01 \mathrm{NS}$ & $0.07 \pm 0.00 \mathrm{a}$ & $9.27 \pm 0.42 b$ & $4.92 \pm 0.93 \mathrm{~b}$ & $0.86 \pm 0.07 \mathrm{c}$ \\
\hline $\mathrm{ACT}$ & $0.13 \pm 0.01 \mathrm{NS}$ & $0.00 \pm 0.00 \mathrm{~b}$ & $0.18 \pm 0.03 \mathrm{a}$ & $0.16 \pm 0.01 \mathrm{a}$ & $0.10 \pm 0.02 \mathrm{NS}$ & $0.05 \pm 0.01 b$ & $12.34 \pm 0.56 \mathrm{a}$ & $10.72 \pm 0.84 \mathrm{a}$ & $1.50 \pm 0.11 \mathrm{a}$ \\
\hline
\end{tabular}

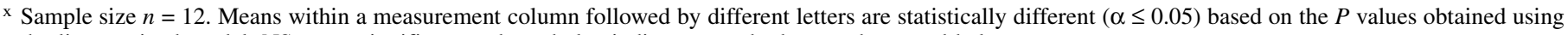
the linear mixed model. NS = not significant and symbol \pm indicates standard error above and below average.

y Fertilization: water control, conventional (Conv), and aerated compost tea (ACT).

z Castasterone and brassinolides are part of the brassinosteroids family, along with homobrassinolides and 24-Epibrassinolides. 
present in ACTs is the plant phylosphere and, when they return to their optimum environment, they are able to survive in the aerial parts of plants and become great competitors against airborne pathogens (Ingham 2005). This form of application could be of interest in future experiments to prevent the entry of $F$. circinatum via stem wounds.

During the pine inoculation assay, two facts were observed. The first was that the symptomatology took longer to appear in the pine fertilized with ACT than with the other two types of fertilization; thus, the severity of the infection depended on something more than plant biometrics. Second, the length and area of the canker of infected plants already showed differences from one treatment to another, with plants fertilized with ACT displaying smaller lesions. The effectiveness of ACT lies not only in the delay and reduction of disease symptoms but also in the increase of the number of asymptomatic plants with respect to conventional fertilization. Not all the asymptomatic plants showed evident tissue damage when the bark was removed; however, those that did could have eliminated or contained the pathogen in some way, which would explain why, after 98 days of duration of the experiment, they did not present greater symptoms. Because of this effect, ACT could be considered as a preventive treatment of the disease.

The amount of fungus found in the pine trees after 98 days postinoculation was noteworthy. The pathogen concentration in the different organs of both symptomatic and nonsymptomatic plants was significantly lower in plants fertilized with ACT, possibly due, in part, to a decrease in inorganic nitrogen content, which would restrict growth and sporulation of fungi (Ingham 2005; Paustian and Schnürer 1987; Treseder and Allen 2002). Surprisingly, the pathogen was detected in the needles surrounding the infected area. That would indicate that it is able to propagate to the vascular tissue once it has colonized the stem, creating a new dispersion vector that needs to be considered when the phytopathogen is detected in nurseries or in the field, although its concentration in needles was found to be lower than in stems.

In addition, it can be seen that the type of fertilization applied influenced the hormonal content of the plant. The higher production of salicylic acid and brassinosteroids observed in inoculated plants fertilized with ACT could have influenced plant defense. O'Donnell et al. (2001) showed that salicylic acid was an important molecule in

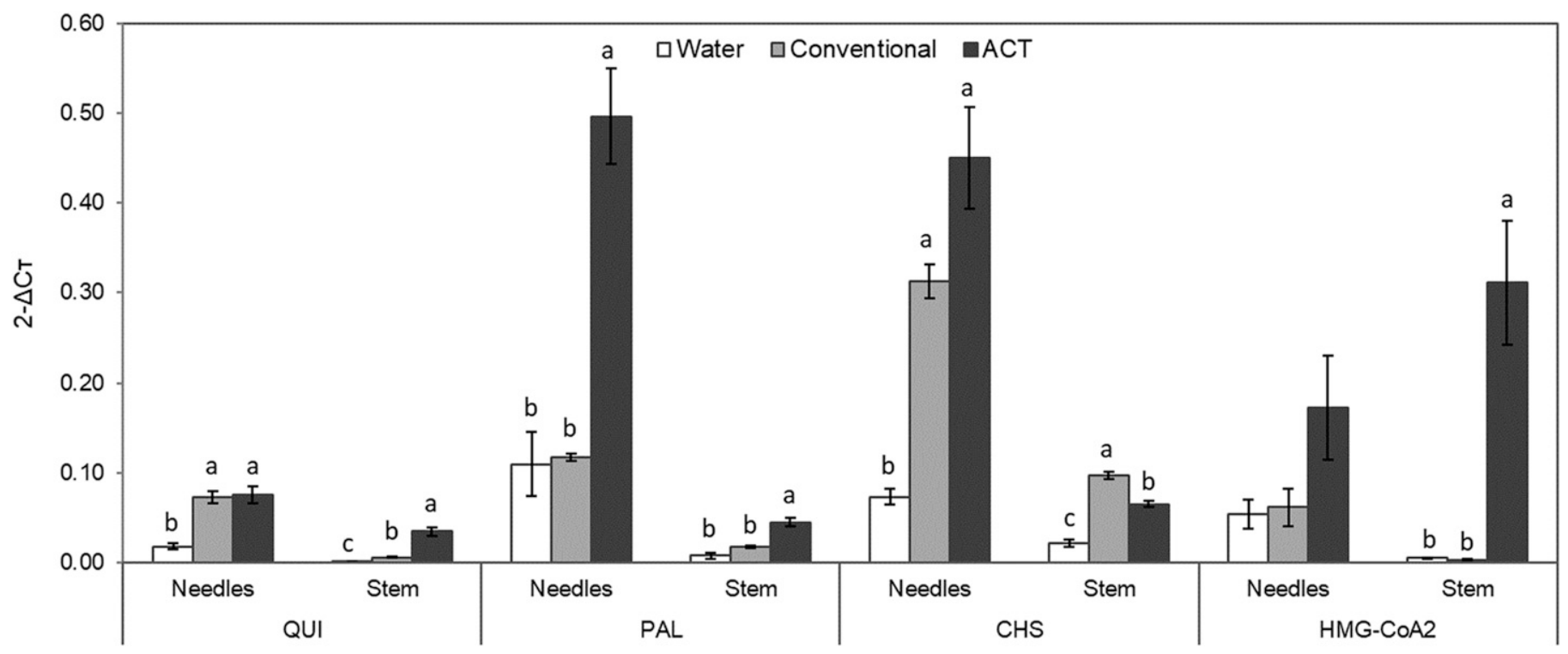

Fig. 4. Fold change in relative expression within Pinus radiata inoculated with Fusarium circinatum over noninoculated plants at 2 days after inoculation. Genes were chitinase $(\mathrm{QUI})$, phenylalanine ammonium-lyase $(\mathrm{PAL})$, chalcone synthase $(\mathrm{CHS})$, and hydroxymethylglutaryl-CoA reductase $2(\mathrm{HMG}-\mathrm{CoA} 2)$. Sample size $=6$. ACT $=$ aerated compost tea. Means with different letters within each variable are statistically different $(\alpha \leq 0.05)$ based on the $P$ values obtained using the analysis of variance test. Error bars indicate the standard error.
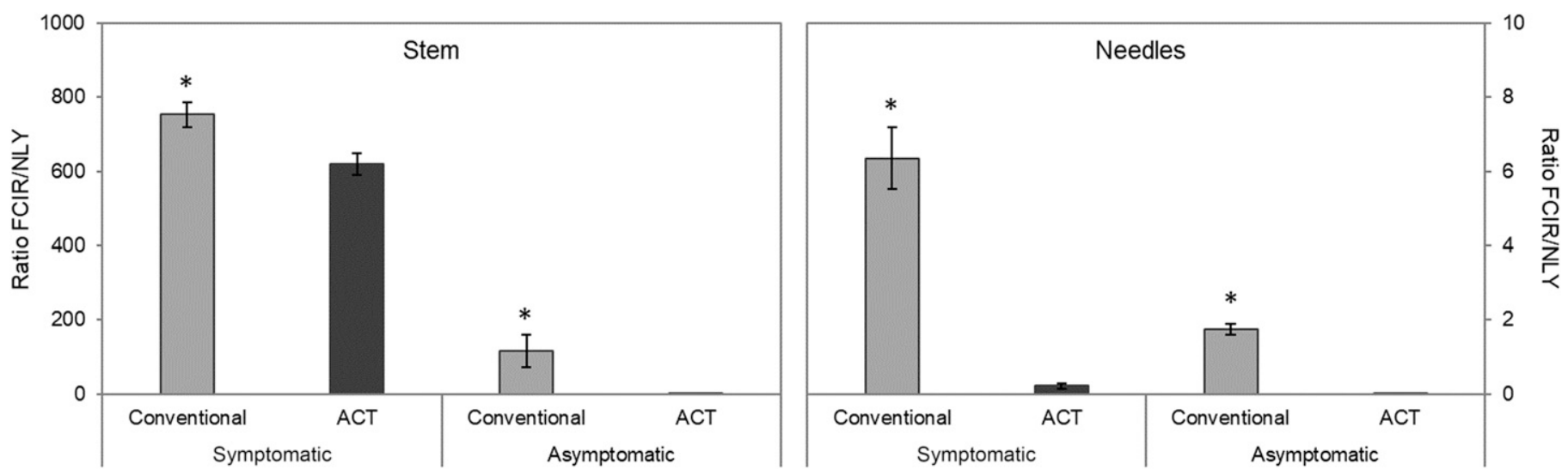

Fig. 5. Absolute quantification of the DNA of Fusarium circinatum in stems and needles of symptomatic and asymptomatic Pinus radiata plants, grown for 18 months with water, conventional fertilizer, and aerated compost tea (ACT). FCIR is the reference gene for detecting $F$. circinatum and $N L Y$ is the gene used as housekeeping. Asterisks indicate significant differences according to the $t$ test. Sample size $=6$. Error bars indicate the standard error. 
disease response, because they observed a correlation between salicylic acid accumulation in infected tissues and necrosis, which would prevent the spread of the pathogen and decrease its concentration. In addition, De Torres Zabala et al. (2009) pointed out that jasmonic acid is unlikely to contribute to early stages of infection and that, if it appears, it is probably because of a wound, as happened in our study in plants irrigated with water at 2 days postinoculation, where jasmonic acid was detected.

The increase in brassinolides in ACT-fertilized plants may have contributed to the decrease in pitch canker. It has been discovered that brassinolides, which have traditionally been related with the plant growth hormone regulation, also have the ability to induce resistance to infection in tobacco and rice plants against viruses, bacteria, and fungi (Nakashita et al. 2003; Wang 2012). According to these authors, the resistance mediated by brassinolides does not require the biosynthesis of salicylic acid and does not lead protein PR expression; therefore, it seems not to be related to systemic acquired resistance.

Although disease severity was lower in ACT-treated plants, more resin was produced by conventionally fertilized plants. Resin is one of the main defenses of Pinus spp. to seal wounds and expel or trap invasive organisms (Morse et al. 2004; Phillips and Croteau 1999). Resin also contains effective compounds for inhibiting phytopathogens such as monoterpenes, diterpenes, and sesquiterpenes (Mumm and Hilker 2006; Nagy et al. 2006), which might be found in greater concentration in the resin of ACT-fertilized plants. Determining qualitatively and quantitatively the presence of these organic compounds could be an interesting analysis for future studies.

Our finding that selected defense genes were upregulated to a higher degree in ACT-fertilized plants when compared with conventionally fertilized plants agrees with previous studies on the influence of CTs on plant defense. These studies have proven that crop fertilization with CTs improves the hosts' defenses by reducing susceptibility to phytopathogenic infection through the induction of synthesis of various enzymes with oxidase activity such as peroxidase and polyphenol oxidase, or involved in the synthesis of phenolic compounds such as PAL (Chittoor et al. 1990; Siddiqui et al. 2009; Weltzien 1991). In our study, both PAL and CHS genes, which codify for enzymes involved in production of compounds with proven antimicrobial activity such as flavonoids, phenylpropanoids, and phytoalexins (Azcón-Bieto and Talón 2008; Donoso et al. 2015), are expressed to a high degree in the plants fertilized with ACT. QUI or HMG-COA2 codifying genes, involved in isoprenoid synthesis, are also overexpressed in ACT-fertilized plants. In particular, isoprenoids play an important role because many of them are involved in defense, given that essential oils or resins have antimicrobial activity (Azcón-Bieto and Talón 2008). A greater expression of these genes inoculated in ACT-fertilized pine could explain the differences in concentration of $F$. circinatum found in comparison with the other two types of fertilization, because an increase in defenses in the short term would reduce the amount of fungus that could colonize the xylem through the cortex.

Conclusions. Applying ACT during the growth phase of $P$. radiata in a nursery reduces the mortality rate and the severity of both external and internal symptoms caused by infection by the pathogen F. circinatum. In addition, this type of fertilization favors the defensive capabilities of the plant by stimulating its defense mechanisms and fostering a hostile environment that hinders the advancement of the infection, thus helping to reduce susceptibility to the pathogen.

\section{ACKNOWLEDGMENTS}

We thank the members of BASALAN S.A. and the Forestry Service of the Provincial Council of Bizkaia for their invaluable assistance provided during the experiment, and the anonymous reviewers for their constructive comments, which have improved this article.

\section{LITERATURE CITED}

Allona, I., Collada, C., Casado, R., Paz-Ares, J., and Aragoncillo, C. 1996. Bacterial expression of an active class Ib chitinase from Castanea sativa cotyledons. Plant Mol. Biol. 32:1171-1176.

Azcón-Bieto, J., and Talón, M. 2008. Fundamentos de Fisiología Vegetal. McGraw-Hill Interamericana, Madrid, Spain.

Bengtsson, J., Ahnström, J., and Weibull, A.-C. 2005. The effects of organic agriculture on biodiversity and abundance: A meta-analysis. J. Appl. Ecol. 42:261-269.

Blodgett, J. T., Herms, D. A., and Bonello, P. 2005. Effects of fertilization on red pine defense chemistry and resistance to Sphaeropsis sapinea. For. Ecol. Manage. 208:373-382.

Boava, L. P., Laia, M. L., Jacob, T. R., Dabbas, K. M., Gonçalves, J. F., Ferro, J. A., Ferro, M. I., and Furtado, E. L. 2010. Selection of endogenous genes for gene expression studies in Eucalyptus under biotic (Puccinia psidii) and abiotic (acibenzolar-S-methyl) stresses using RT-qPCR. BMC Res. Notes 3: 43.

Bonello, P., and Blodgett, J. T. 2003. Pinus nigra-Sphaeropsis sapinea as a model pathosystem to investigate local and systemic effects of fungal infection of pines. Physiol. Mol. Plant Pathol. 63:249-261.

Britz, H., Couhnho, T. A., Gordon, T. R., and Wingfield, M. J. 2001. Characterisation of the pitch canker fungus, Fusarium circinatum, from Mexico. S. Afr. J. Bot. 67:609-614.

Caporaso, J. G., Kuczynski, J., Stombaugh, J., Bittinger, K., Bushman, F. D., Costello, E. K., Fierer, N., Peña, A. G., Goodrich, J. K., Gordon, J. I., Huttley, G. A., Kelley, S. T., Knights, D., Koenig, J. E., Ley, R. E., Lozupone, C. A., McDonald, D., Muegge, B. D., Pirrung, M., Reeder, J., Sevinsky, J. R., Turnbaugh, P. J., Walters, W. A., Widmann, J., Yatsunenko, T., Zaneveld, J., and Knight, R. 2010. QIIME allows analysis of highthroughput community sequencing data. Nat. Methods 7:335-336.

Chang, S., Puryear, J., and Cairney, J. 1993. A simple and efficient method for isolating RNA from pine trees. Plant Mol. Biol. Rep. 11:113-116.

Cheah, L. H., and Page, B. B. C. 1997. Trichoderma spp. for potential biocontrol of clubroot of vegetable brassicas. N. Z. Plant Prot. 50:150-153.

Cheng, Z., Park, E., and Glick, B. R. 2007. 1-Aminocyclopropane-1carboxylate deaminase from Pseudomonas putida UW4 facilitates the growth of canola in the presence of salt. Can. J. Microbiol. 53:912-918.

Chittoor, J. M., Leach, J. E., and White, F. F. 1990. Induction of peroxidase during defense against pathogens. Page 291 in: Pathogenesis: Related Proteins in Plants. S. K. Datta and S. Muthukrishnan, eds. CRC Press, Boca Raton, FL, U.S.A.

Correll, J. C., Gordon, T. R., McCain, A. H., Fox, J. W., Koehler, C. S., Wood, D. L., and Schultz, M. E. 1991. Pitch canker disease in California: Pathogenicity, distribution and canker development on Monterey pines (Pinus radiata). Plant Dis. 75:676-682.

De Keyser, E., Desmet, L., Van Bockstaele, E., and De Riek, J. 2013. How to perform RT-qPCR accurately in plant species? A case study on flower colour gene expression in an azalea (Rhododendron simsii hybrids) mapping population. BMC Mol. Biol. 14:13.

De Torres Zabala, M., Bennett, M. H., Truman, W. H., and Grant, M. R. 2009. Antagonism between salicylic and abscisic acid reflects early host-pathogen conflict and moulds plant defence responses. Plant J. 59: 375-386.

Domracheva, L. I., Shirokikh, I. G., and Fokina, A. I. 2010. Anti-Fusarium activity of cyanobacteria and actinomycetes in soil and rhizosphere. Microbiology 79:871-876.

Donoso, A., Rodriguez, V., Carrasco, A., Ahumada, R., Sanfuentes, E., and Valenzuela, S. 2015. Relative expression of seven candidate genes for pathogen resistance on Pinus radiata infected with Fusarium circinatum. Physiol. Mol. Plant Pathol. 92:42-50.

Droffner, M. L., Brinton, W. F., and Evans, E. 1995. Evidence for the prominence of well characterized mesophilic bacteria in thermophilic $\left(50-70^{\circ} \mathrm{C}\right)$ composting environments. Biomass Bioenergy 8:191-195.

Edgar, R. C. 2010. Search and clustering orders of magnitude faster than BLAST. Bioinformatics 26:2460-2461.

Eng, F., Gutiérrez-Rojas, M., and Favela-Torres, E. 2003. Efecto de la temperatura y el $\mathrm{pH}$ en el crecimiento superficial de Botryodiplodia theobromae. Rev. Iberoam. Micol. 20:172-175.

Gordon, T. R. 2006. Pitch canker disease of pines. Phytopathology 96: 657-659.

Gutiérrez-Mañero, F. J., Ramos-Solano, B., Probanza, A., Mehouachi, J., Tadeo, F. R., and Talon, M. 2001. The plant-growth-promoting rhizobacteria Bacillus pumilus and Bacillus licheniformis produce high amounts of physiologically active gibberellins. Physiol. Plant. 111:206-211.

Hameeda, B., Harini, G., Rupela, O. P., Wani, S. P., and Reddy, G. 2008. Growth promotion of maize by phosphate-solubilizing bacteria isolated from composts and macrofauna. Microbiol. Res. 163:234-242. 
Hepting, G. H., and Roth, E. R. 1946. Pitch canker, a new disease of some southern pines. J. For. 44:742-744.

Ingham, E. R. 2005. The Compost Tea Brewing Manual, 5th ed. Soil Food International Inc., Corvallis, OR.

Iqbal, S., Hameed, S., Sharid, M., Hussain, K., Ahmad, K., and Niaz, M. 2018. In vitro characterization of bacterial endophytes from tomato (Solanum lycopersicum L.) for phytobeneficial traits. Appl. Ecol. Environ. Res. 16: 1037-1051.

Jin, Q., Yao, Y., Cai, Y., and Lin, Y. 2013. Molecular cloning and sequence analysis of a phenylalanine ammonia-lyase gene from Dendrobium. PLoS One 8:e62352.

Kai, H., Ueda, T., and Sakaguchi, M. 1990. Antimicrobial activity of barkcompost extracts. Soil Biol. Biochem. 22:983-986.

Kim, M. J., Shim, C. K., Kim, Y. K., Hong, S. J., Park, J. H., Han, E. J., Kim, J. H., and Kim, S. C. 2015. Effect of aerated compost tea on the growth promotion of lettuce, soybean, and sweet corn in organic cultivation. Plant Pathol. J. 31:259-268.

Konishi, H., Ishiguro, K., and Komatsu, S. 2001. A proteomics approach towards understanding blast fungus infection of rice grown under different levels of nitrogen fertilization. Proteomics 1:1162-1171.

Landeras, E., García, P., Fernández, Y., Braña, M., Fernández-Alonso, O., Méndez-Lodos, S., Pérez-Sierra, A., León, M., Abad-Campos, P., Berbegal, M., Beltrán, R., García-Jiménez, J., and Armengol, J. 2005. Outbreak of pitch canker caused by Fusarium circinatum on Pinus spp. in northern Spain. Plant Dis. 89:1015.

Lateef, A., Adelere, I. A., and Gueguim-Kana, E. B. 2015. The biology and potential biotechnological applications of Bacillus safensis. Biologia 70: 411-419.

Martín-Rodrigues, N., Espinel, S., Sanchez-Zabala, J., Ortiz, A., Gonzalez-Murua, C., and Dunabeitia, M. K. 2013. Spatial and temporal dynamics of the colonization of Pinus radiata by Fusarium circinatum, of conidiophora development in the pith and of traumatic resin duct formation. New Phytol. 198:1215-1227.

Martín-Rodrigues, N., Sanchez-Zabala, J., Salcedo, I., Majada, J., González-Murua, C., and Duñabeitia, M. K. 2015. New insights into radiata pine seedling root infection by Fusarium circinatum. Plant Pathol. 64: 1336-1348.

Möller, E. M., Bahnweg, G., Sandermann, H., and Geiger, H. H. 1992. A simple and efficient protocol for isolation of high molecular weight DNA from filamentous fungi, fruit bodies, and infected plant tissues. Nucleic Acids Res. 20:6115-6116.

Morse, A. M., Nelson, C. D., Covert, S. F., Holliday, A. G., Smith, K. E., and Davis, J. M. 2004. Pine genes regulated by the necrotrophic pathogen Fusarium circinatum. Theor. Appl. Genet. 109:922-932.

Mumm, R., and Hilker, M. 2006. Direct and indirect chemical defence of pine against folivorous insects. Trends Plant Sci. 11:351-358.

Murray, M. G., and Thompson, W. F. 1980. Rapid isolation of high molecular weight plant DNA. Nucleic Acids Res. 8:4321-4326.

Nagy, N. E., Krokene, P., and Solheim, H. 2006. Anatomical-based defense responses of Scots pine (Pinus sylvestris) stems to two fungal pathogens. Tree Physiol. 26:159-167.

Naidu, Y., Meon, S., Kadir, J., and Siddiqui, Y. 2010. Microbial starter for the enhancement of biological activity of compost tea. Int. J. Agric. Biol. 12: 51-56.

Nakashita, H., Yasuda, M., Nitta, T., Asami, T., Fujioka, S., Arai, Y., Sekimata, K., Takatsuto, S., Yamaguchi, I., and Yoshida, S. 2003. Brassinosteroid functions in a broad range of disease resistance in tobacco and rice. Plant J. 33:887-898.

Nirenberg, H. I., and O’Donnell, K. 1998. New Fusarium species and combinations within the Gibberella fujikuroi species complex. Mycologia 90: 434-458.

O’Donnell, K., Cigelnik, E., and Nirenberg, H. I. 1998. Molecular systematics and phylogeography of the Gibberella fujikuroi species complex. Mycologia 90:465-493.

O’Donnell, P., Jones, J. B., Antoine, F. R., Ciardi, J., and Klee, H. J. 2001. Ethylene-dependent salicylic acid regulates an expanded cell death response to a plant pathogen. Plant J. 25:315-323.

Ortega, U., Majada, J., Mena-Petite, A., Sanchez-Zabala, J., Rodriguez-Iturrizar, N., Txarterina, K., Azpitarte, J., and Duñabeitia, M. 2006. Field performance of Pinus radiata D. Don produced in nursery with different types of containers. New For. 31:97-112.

Otero, M., Salcedo, I., Txarterina, K., Gonzalez-Murua, C., and Duñabeitia, M. K. 2019. Quality assessment of Pinus radiata production under sustainable nursery management based on compost tea. J. Plant Nutr. Soil Sci. 182:356-366

Palmer, A. K., Evans, K. J., and Metcalf, D. A. 2010. Characters of aerated compost tea from immature compost that limit colonization of bean leaflets by Botrytis cinerea. J. Appl. Microbiol. 109:1619-1631.

Patten, C. L., and Glick, B. R. 2002. Role of Pseudomonas putida Indoleacetic acid in development of the host plant root system. Appl. Environ. Microbiol. 68:3795-3801.

Paustian, K., and Schnürer, J. 1987. Fungal growth response to carbon and nitrogen limitation: A theoretical model. Soil Biol. Biochem. 19:613-620.

Pérez-Sierra, A., Landeras, E., León, M., Berbegal, M., García-Jiménez, J., and Armengol, J. 2007. Characterization of Fusarium circinatum from Pinus spp. in northern Spain. Mycol. Res. 111:832-839.

Phillips, M. A., and Croteau, R. B. 1999. Resin-based defenses in conifers. Trends Plant Sci. 4:184-190.

Reglinski, T., Taylor, J. T., and Dick, M. A. 2004. Chitosan induces resistance to pitch canker in Pinus radiata. N. Z. J. For. Sci. 31:49-58.

Rivera, M. E., Codina, J. C., Olea, F., De Vicente, A., and Pérez-García, A. 2002. Differential expression of B-1,3-glucanase in susceptible and resistant melon cultivars in response to infection by Sphaerotheca fusca. Physiol. Mol. Plant Pathol. 61:257-265.

Scheuerell, S., and Mahaffee, W. 2002. Compost tea: Principles and prospects for plant disease control. Compost Sci. Util. 10:313-338.

Scheuerell, S. J., and Mahaffee, W. F. 2004. Compost tea as a container medium drench for suppressing seedling damping-off caused by Pythium ultimum. Phytopathology 94:1156-1163.

Schweigkofler, W., O'Donnell, K., and Garbelotto, M. 2004. Detection and quantification of airborne conidia of Fusarium circinatum, the causal agent of pine pitch canker, from two California sites by using a real-time PCR approach combined with a simple spore trapping method. Appl. Environ. Microbiol. 70:3512-3520.

Selvakumar, G., Mohan, M., Kundu, S., Gupta, A. D., Joshi, P., Nazim, S., and Gupta, H. S. 2008. Cold tolerance and plant growth promotion potential of Serratia marcescens strain SRM (MTCC 8708) isolated from flowers of summer squash (Cucurbita pepo). Lett. Appl. Microbiol. 46:171-175.

Shaharoona, B., Naveed, M., Arshad, M., and Zahir, Z. A. 2008. Fertilizerdependent efficiency of Pseudomonads for improving growth, yield, and nutrient use efficiency of wheat (Triticum aestivum L.). Appl. Microbiol. Biotechnol. 79:147-155.

Siddiqui, Y., Meon, S., Ismail, R., and Rahmani, M. 2009. Bio-potential of compost tea from agro-waste to suppress Choanephora cucurbitarum L. the causal pathogen of wet rot of okra. Biol. Control 49:38-44.

Steenkamp, E. T., Rodas, C. A., Kvas, M., and Wingfield, M. J. 2012. Fusarium circinatum and pitch canker of Pinus in Colombia. Australas. Plant Pathol. 41:483-491.

Treseder, K. K., and Allen, M. F. 2002. Direct nitrogen and phosphorus limitation of arbuscular mycorrhizal fungi: A model and field test. New Phytol. 155:507-515.

Veluthakkal, R., and Dasgupta, M. G. 2010. Pathogenesis-related genes and proteins in forest tree species. Trees (Berl.) 24:993-1006.

Viljoen, A., Wingfield, M. J., and Marasas, W. F. O. 1994. First report of Fusarium subglutinans f. sp. pini on pine seedlings in South Africa. Plant Dis. 78:309-312.

Villar-Luna, E., Rojas-Martínez, R., Reyes-Trejo, B., Rocha-Sosa, M., and Zavaleta-Mejía, E. 2015. Expresión del gen HMG2 (HidroximetilglutarilCoA reductasa 2) en chile (Capsicum annuum L.) CM334 infectado por Nacobbus aberrans y Phytophthora capsici. Agrociencia 49:69-75.

Wang, Z.-Y. 2012. Brassinosteroids modulate plant immunity at multiple levels. Proc. Natl. Acad. Sci. U.S.A. 109:7-8.

Welke, S. E. 2005. The effect of Compost Extract on the yield of strawberries and the severity of Botrytis cinerea. J. Sustain. Agric. 25:57-68.

Weltzien, H. C. 1991. Biocontrol of foliar fungal disease with compost extracts. Pages 430-450 in: Microbial Ecology of Leaves. J. H. Andrews and S. S. Hirano, eds. Springer-Verlag, New York, NY, U.S.A.

Wingfield, M. J., Hammerbacher, A., Ganley, R. J., Steenkamp, E. T., Gordon, T. R., Wingfield, B. D., and Coutinho, T. A. 2008. Pitch canker caused by Fusarium circinatum-A growing threat to pine plantations and forests worldwide. Australas. Plant Pathol. 37:319-334.

Wingfield, M. J., Slippers, B., Roux, J., and Wingfield, B. D. 2001. Worldwide movement of exotic forest fungi, especially in the tropics and the southern hemisphere: This article examines the impact of fungal pathogens introduced in plantation forestry. Bioscience 51:134-140. 